Materiales de Construcción

Vol. 70, Issue 338, April-June 2020, e220

ISSN-L: 0465-2746

https://doi.org/10.3989/mc.2020.13819

\title{
Preliminary study on the upcycle of non-structural construction and demolition waste for waste cleaning
}

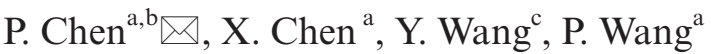 \\ a. School of Civil Engineering and Architecture, Anhui University of Science and Technology, Huainan, P.R. China \\ b. Hefei Construction Engineering Group Co., P. R. China \\ c. School of Civil Engineering, Wuhan University, P. R. China \\ $\triangle$ peiyuan29@126.com
}

Received 10 October 2019

Accepted 10 January 2020

Available on line 15 April 2020

\begin{abstract}
This study proposes a method to convert non-structural calcium-rich construction and demolition waste fines into adsorbents of heavy metal ions by mixing waste fines with diammonium hydrogen phosphate solution to produce hydroxyapatite, which has high surface areas and excellent ion-exchange capacity with heavy metal ions. As a result, environmental polluting waste is converted into environmentally cleaning material. Waste putty powders was chosen as the representative waste to investigate the detailed formation process of hydroxyapatite and the key reaction parameters of the reaction. Results showed that hydroxyapatite can be produced on waste putty particles. Higher ageing temperatures or longer ageing duration are beneficial to the yield and crystallinity of the produced hydroxyapatite. Adsorption testing confirmed that $\mathrm{Ni}^{2+}$ can replace $\mathrm{Ca}^{2+}$ in the hydroxyapatite lattice, leading to the formation of a new crystal, arupite $\left(\mathrm{Ni}_{3}\left(\mathrm{PO}_{4}\right)_{2} \bullet 8 \mathrm{H}_{2} \mathrm{O}\right)$, and contributing to a modest adsorption capacity for $\mathrm{Ni}^{2+}(15 \mathrm{mg} / \mathrm{g})$ for the hydroxyapatite-containing waste putty.
\end{abstract}

KEYWORDS: Concrete; Heavy metals; Waste treatment; Adsorption; Characterization.

Citation/Citar como: Chen, P.; Chen, X.; Wang, Y.; Wang, P. (2020) Preliminary Study on the Upcycle of Non-structural Construction and Demolition Waste for Waste Cleaning. Mater. Construcc. 70 [338], e220 https://doi.org/10.3989/ mc.2020.13819

RESUMEN: Estudio preliminar sobre el empleo de residuos de construcción y demolición no estructurales para la eliminación de residuos. Este estudio propone un método para convertir residuos de construcción y demolición no estructurales, ricos en calcio y pulverulentos, en adsorbentes de iones de metales pesados mezclándolos con una solución de hidrógenofosfato de diamonio para generar hidroxiapatita, la cual presenta una elevada área superficial y una excelente capacidad de intercambio iónico de iones de metales pesados. De este modo, un residuo contaminante se convierte en un material que limpia el medio ambiente. Se seleccionó residuo en forma de masilla en polvo como residuo representativo para investigar en detalle los procesos de formación de hidroxiapatita y los parámetros clave implicados en la reacción. Los resultados mostraron que la hidroxiapatita se puede producir en las partículas de los residuos empleados. La producción y la cristalinidad de la hidroxiapatita se ve favorecida por temperaturas de envejecimiento elevadas y prolongadas. Los ensayos de adsorción confirmaron que el $\mathrm{Ni}^{2+}$ puede sustituir al $\mathrm{Ca}^{2+}$ en la estructura de la hidroxiapatita, formándose un nuevo mineral, arupita $\left(\mathrm{Ni}_{3}\left(\mathrm{PO}_{4}\right)_{2} \bullet 8 \mathrm{H}_{2} \mathrm{O}\right)$, y contribuyendo a una adsorción modesta de $\mathrm{Ni}^{2+}(15 \mathrm{mg} / \mathrm{g})$ por parte de la masilla de residuos con hidroxiapatita.

PALABRAS CLAVE: Hormigón; Metales pesados; Tratamiento de residuos; Adsorción; Caracterización.

ORCID ID: P. Chen (https://orcid.org/0000-0002-5538-617X); X. Chen (https://orcid.org/0000-0002-6451-0283); Y. Wang (https://orcid.org/0000-0001-8935-5956); P. Wang (https://orcid.org/0000-0002-7229-6061)

Copyright: (C) 2020 CSIC. This is an open-access article distributed under the terms of the Creative Commons Attribution 4.0 International (CC BY 4.0) License. 


\section{INTRODUCTION}

An estimated 2 billion tons of construction and demolition (C\&D) wastes are produced each year globally. These wastes create enormous negative effects on the environment in terms of land occupation and environmental pollutions of land, water, and air (1-4). Recycling the $C \& D$ wastes for new applications is the most promising way to combat the negative impacts of C\&D wastes as well as resources recycling. Generally, C\&D wastes are classified into structural and non-structural wastes depending on their qualities and mechanical properties. For instance, waste and demolished concrete is such kind of structural waste with high mechanical properties. It can be crushed into particles and can be used as recycled concrete aggregates (RCAs) in new concrete, which is well known as recycling concrete (RC) $(1,5-10)$. Every year, abundant studies on manufacturing methods and properties of RCAs as well as the fresh and hardened properties of RCA-incorporated $\mathrm{RC}$ are carried out worldwide, contributing towards the progress of recycling such waste. Nevertheless, decorative construction waste, a characteristic kind of non-structural waste, receives very little attention in the last few decades towards to its reuse.

Construction putty is one of the widely applied decorative materials on the surface of building components to fill cracks, scratches, and other irregularities such that a smooth surface is formed for subsequent paint and varnish. Normally, a thickness of $20 \mathrm{~mm}$ and $50 \mathrm{~mm}$ of construction putty (or about $1 \mathrm{~kg} / \mathrm{m}^{2}$ ) is required for coating building components. Thus, one can expect that a huge amount of waste construction putty (WP) is correspondingly produced globally along with the two billion tons of C\&D wastes each year. By now, in addition to landfill or as partial filler for subgrade, effective reuse methods of WP are rarely reported, possibly due to issues such as cost efficiency and reuse technology. In particular, reuse of WP with inferior mechanical properties cannot be focused without value added technology. This paper intends to fill this gap to develop a value added reuse technology for WP based on a wet chemical method to convert WP into an adsorbent of heavy metals. Hydroxyapatite (HAP), with the ideal formula $\mathrm{Ca}_{10}\left(\mathrm{PO}_{4}\right)_{6}(\mathrm{OH})_{2}$, is chosen as the target adsorbent in this method. HAP belongs to the apatite family and commonly exists in natural bones and teeth (11-14). It has salient features in terms of high stability, good biocompatibility, high bioactivity, and high sorption capacity $(12,15-17)$. Particularly, HAP possesses the salient capacity of adsorbing heavy metal ions through a so-called ion-exchange process $(18,19)$. The ion-exchange mechanism is shown in Equation [1]:
$\mathrm{Ca}_{10}\left(\mathrm{PO}_{4}\right)_{6}(\mathrm{OH})_{2}+x \mathrm{M}^{2+} \rightarrow\left(\mathrm{Ca}_{10-\mathrm{x}} \mathrm{M}_{\mathrm{x}}\right)$

$\left(\mathrm{PO}_{4}\right)_{6}(\mathrm{OH})_{2}+x \mathrm{Ca}^{2+}$,

where $M=\mathrm{Pb}, \mathrm{Zn}, \mathrm{Ni}$, or $\mathrm{Cd}$, and $0 \leq x \leq 10$.

Equation [1] suggests that heavy metal ions can replace the calcium in the lattice of HAP. A maximum of 10 heavy metal units can be strongly stabilized by one HAP unit. The adsorption capability of HAP on a variety of toxic metal ions has been successfully confirmed, such as $\mathrm{Co}^{2+}, \mathrm{Cu}^{2+}$, $\mathrm{Cd}^{2+}, \mathrm{Zn}^{2+}, \mathrm{Ni}^{2+}$, and $\mathrm{Pb}^{2+}(15,16,20,21)$. Thus, HAP is regarded as an excellent adsorption and stabilization material for radioactive waste and harmful metals $(12,22)$. In the past thirty years, there has been a great interest worldwide in the synthetic methods of HAP powders. As summarized by Fihri (12) those methods are classified into four categories: dry methods (23), wet methods $(13,15)$, microwave-assisted methods $(24,25)$ and miscellaneous methods. Among them, the wet methods, including double decomposition or coprecipitation, emulsion, hydrolysis method, sol-gel method, and hydrothermal approach, are widely adopted since the procedures for these methods are simple and allow perfect control on the structure, texture, and morphology of HAP powders (12).

In the case that HAP contains calcium and $\mathrm{PO}_{4}{ }^{2-}$ as its substantial constituents, and that calcium-rich minerals, i.e., calcium carbonate, lime, and calcium-magnesium fine particles are commonly used in construction putty as the filler (26), it was proposed to use WP as the calcium source to produce HAP by soaking WP into a phosphate solution such as diammonium hydrogen phosphate $\left(\left(\mathrm{NH}_{4}\right)_{2} \mathrm{HPO}_{4}, \mathrm{DAP}\right)$. Through this method, the non-structural waste (WP) can be converted into high-value environmental cleaning materials as heavy metal adsorbents. This might evoke great attention to its recycling.

To demonstrate the feasibility of the proposed approach, a preliminary study was carried out in this paper to investigate the detailed formation process of HAP and the key reaction parameters of the reaction between WP and DAP solution. The produced WP-HAP particles were comprehensively characterized by scanning electron microscopy (SEM), X-ray diffraction (XRD), Energy-dispersive X-ray spectroscopy (EDS), and Brunauer, Emmett, and Teller (BET) methods. Moreover, the ion-exchange of the produced WP-HAP powder with $\mathrm{Ni}^{2+}$ (that is commonly used in refining, steel, welding, and electroplating industries and is one of the most harmful toxic metal to human beings even in small quantities that can cause lung fibrosis, kidney disease, and allergic dermatitis $(15,27)$ ) was confirmed by an 
adsorption experiment. This approach is particularly suitable for calcium-rich non-structural C\&D wastes that are difficult to recycle as new construction and building materials due to their inferior mechanical properties.

\section{MATERIALS AND METHODS}

\subsection{Materials}

WP was collected from interior walls of a discarded building in the old campus of Anhui University of Science and Technology, China. Its chemical components and mineral composition were examined by X-ray fluorescence (XRF) and $\mathrm{XRD}$, respectively, as shown in Table 1 and Figure 1. Table 1 shows that $\mathrm{C}, \mathrm{Ca}$ and $\mathrm{Mg}$ are the major elements along with small amount of $\mathrm{S}, \mathrm{Si}, \mathrm{Al}, \mathrm{Fe}, \mathrm{Na}$ and $\mathrm{K}$ in the putty sample. Figure 1 suggests that the WP is mainly consisted of dolomite $\left(\mathrm{CaMg}\left(\mathrm{CO}_{3}\right)_{2}\right.$, JCPDS, No. 99-0046) and calcite $\left(\mathrm{CaCO}_{3}\right.$, JCPDS, No. 86-0174), accompanied by small amount of quartz $\left(\mathrm{SiO}_{2}\right.$ JCPDS, No. 85-0798) and glauberite $\left(\mathrm{CaNa}_{2}\left(\mathrm{SO}_{4}\right)_{2}, \mathrm{JCPDS}\right.$, No. $\left.74-1065\right)$, as marked in the figure.

WP was first grounded into fine powder passing through a 200 -mesh sieve (less than $75 \mu \mathrm{m}$ ) and then dried in an oven at $150{ }^{\circ} \mathrm{C}$ for 24 hours until mass equilibrium was reached. $\left(\mathrm{NH}_{4}\right)_{2} \mathrm{HPO}_{4}$ (DAP) and $\mathrm{NiSO}_{4} \cdot 6 \mathrm{H}_{2} \mathrm{O}$ of analysis purity without further purification were purchased from the Sinopharm Chemical Reagent Co., Ltd. Tap water was used throughout this study with an aim to maintain the cost of the proposed process to the minimum.

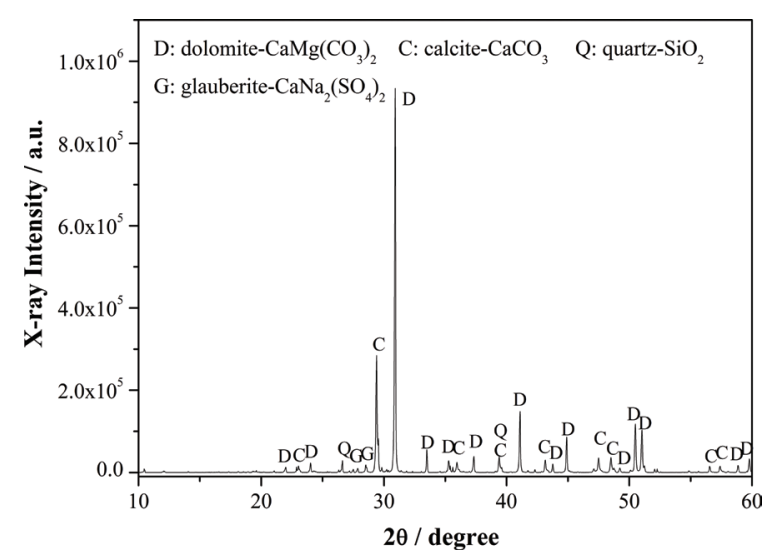

FIGURE 1. XRD pattern of the waste construction putty.

\subsection{Preparation of WP-HAP Powder}

WP-HAP powder was prepared based on the chemical reaction between DAP solution and the WP. This reaction is determined by two major factors: aging temperature and duration. Three aging temperatures $\left(23^{\circ} \mathrm{C}, 50^{\circ} \mathrm{C}\right.$ and $\left.80^{\circ} \mathrm{C}\right)$ and four aging durations (3, 9, 15 and 21 days) were used in the study to evaluate their effects on the morphological and mineralogical properties of the WP-HAP.

In a typical procedure, $200 \mathrm{ml} 2 \mathrm{M}$ DAP solution was initially prepared in a beaker. $133.6 \mathrm{~g} \mathrm{WP}$ powder was then added into it to achieve a $\mathrm{Ca} / \mathrm{P}$ ratio of 1.67 , at which the produced HAP crystal may have a similar structure as those existing in bones and teeth (12). The mixture was vigorously stirred for $5 \mathrm{~min}$ and then aged in the sealed beaker to allow for the chemical reaction between the putty powder and the DAP to produce HAP. At the end of each aging duration, the mixture was filtered, washed and finally dried at $105^{\circ} \mathrm{C}$ for 24 hours for further analysis and adsorption testing. The produced WP-HAP samples were named as $X \mathrm{~d} Y$, where $X \mathrm{~d}$ is the aging duration in days, and $Y$ is the aging temperature in Celsius. For example, $3 \mathrm{~d} 50$ refers to a WP-HAP sample produced by aging at $50^{\circ} \mathrm{C}$ for 3 days.

\subsection{Adsorption Experiment}

A simple adsorption experiment was conducted under ambient temperature and pressure to confirm that the produced WP-HAP powder can adsorb $\mathrm{Ni}^{2+}$ through the ion-change process. The waste solution with heavy metal ions was simulated by mixing $\mathrm{NiSO}_{4} \cdot 6 \mathrm{H}_{2} \mathrm{O}$ with deionized water with the concentration of $\mathrm{Ni}^{2+}$ as $100 \mathrm{mg} / \mathrm{L} .100 \mathrm{ml}$ waste solution was mixed with $0.2 \mathrm{~g} 15 \mathrm{~d} 50 \mathrm{WP}-\mathrm{HAP}$ in a beaker, which was then sealed and shaken at the speed of $100 \mathrm{r} / \mathrm{min}$ by a rotating shaker for 72 hours. After that, the waste solution was filtered and the solid substance on the filter paper was dried at $105^{\circ} \mathrm{C}$ for 24 hours for SEM, EDS, XRD analysis to study the adsorption process of the produced WP-HAP powders. The amount of $\mathrm{Ni}^{2+}$ adsorbed by the WP-HAP was determined by a PerkinElmer optima 7000 Inductively Coupled Plasma Optical Emission Spectrometer (ICP-OES).

\subsection{Characterization Analysis}

Morphological examination and elemental analysis were performed using a S-3400N scanning electron microscopy equipped with X-ray

TABLE 1. Chemical composition of the waste construction putty by XRF

\begin{tabular}{lccccccccc}
\hline Oxide & $\mathbf{C O}_{2}$ & $\mathbf{C a O}$ & $\mathbf{M g O}$ & $\mathbf{S O}_{3}$ & $\mathbf{S i O}_{2}$ & $\mathbf{A l}_{2} \mathbf{O}_{3}$ & $\mathbf{F e}_{2} \mathbf{O}_{3}$ & $\mathbf{N a}_{2} \mathbf{O}$ & $\mathbf{K}_{2} \mathbf{O}$ \\
\hline Content $(\%)$ & 43.6 & 28.0 & 13.7 & 7.9 & 5.6 & 0.6 & 0.2 & 0.2 & 0.1 \\
\hline
\end{tabular}


energy-dispersive spectroscopy. The operating acceleration voltage was $15 \mathrm{kV}$. Samples prepared for SEM observation were coated by a layer of gold particles to improve their electrical conductivity before SEM operation. Mineralogical composition was investigated by a SmartLab 9KW multi-function X-ray powder diffractometer using $\mathrm{Cu} \_\mathrm{K} \alpha$ radiation at $45 \mathrm{kV}$ and $200 \mathrm{~mA}$ at a scan speed of $8^{\circ} / \mathrm{min}$ between $2 \theta$ of $10^{\circ}$ to $60^{\circ}$. Chemical composition of WP was determined by a XRF-1800 X-ray fluorescence spectroscopy. Brunauer, Emmett, and Teller surface area of WP and WP-HAP samples was tested by an ASAP2020 specific surface area and aperture analyzer.

\section{RESULTS AND DISCUSSIONS}

\subsection{Mineralogical Composition of WP-HAP Samples by XRD}

\subsubsection{Effect of Aging Temperature}

Figure 2 shows the XRD patterns of the WP-HAP samples obtained after an aging duration of $3 \mathrm{~d}$. Mineralogical composition of each sample was identified by comparing with standard JCPDS files. Five crystals, namely, dolomite $\left(\mathrm{CaMg}\left(\mathrm{CO}_{3}\right)_{2}\right.$, No. 99-0046), calcite $\left(\mathrm{CaCO}_{3}\right.$, No. 86-0174), monetite $\left(\mathrm{CaHPO}_{4}\right.$, No. 70-1425), farringtonite $\left(\mathrm{Mg}_{3}\left(\mathrm{PO}_{4}\right)_{2}\right.$, No. 75-1491), and hydroxylapatite $\left(\mathrm{Ca}_{10}\left(\mathrm{PO}_{4}\right)_{6}(\mathrm{OH})_{2}\right.$, No. 74-0566) were found as marked in this figure. The last three minerals were not present in the WP and, therefore, were produced by the reaction between WP and the DAP solution.

The contents of these three new minerals are clearly dependent on the aging temperature. For example, the characteristic peaks of HAP were only found in $3 \mathrm{~d} 50$ and $3 \mathrm{~d} 80$. Intermediate phosphate phases such as monetite and farringtonite were formed at the ambient temperature $\left(23^{\circ} \mathrm{C}\right)$. No HAP

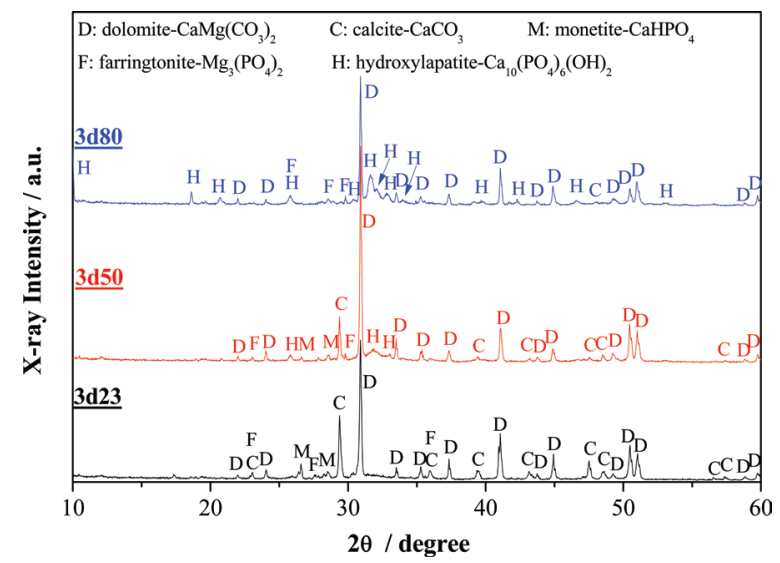

Figure 2. XRD patterns of WP-HAP samples aged for $3 \mathrm{~d}$. was identified in this sample, suggesting that the ambient condition was insufficient to produce HAP only with $3 \mathrm{~d}$ of aging by the proposed method. At a higher aging temperature $\left(50^{\circ} \mathrm{C}\right), \mathrm{HAP}$ appeared in the XRD pattern, and the content of intermediate phosphate phases was greatly reduced. The presence of intermediate phosphate phases suggests one of the drawbacks of wet methods of HAP synthesis that the production of crystallographically pure HAP is challenging when other phases of phosphates are present $(12,15,16)$. As shown in Figure 2, the HAP produced at this temperature has a low crystallinity, as indicated by a hump at $2 \theta=31.9^{\circ}-34.2^{\circ}$ with a broad peak width. When the aging temperature was as high as $80^{\circ} \mathrm{C}$, the peak heights of the produced HAP (especially the one at $2 \theta=31.9^{\circ}$ ) are much higher than those of the $3 \mathrm{~d} 50$. This result suggests that higher aging temperature can improve the yield and crystallinity of the produced HAP $(14,28,29)$. Figure 2 also shows that the heights of peaks corresponding to dolomite, monetite, and calcite reduced when more HAP was produced, and when calcite and dolomite in the WP were consumed by the DAP solution to generate HAP.

The effect of aging temperature on the mineralogical composition of the produced WP-HAP made with a longer aging duration (15 d) is displayed in Figure 3. No significant difference can be found between the mineralogical compositions of the WP-HAP produced with an aging duration of 15 d or 3 d. Similar to Figure 2, higher crystallinity of the produced HAP was achieved at higher aging temperature, as displayed by the higher and sharper HAP peaks in the XRD patterns shown in Figure 3.

\subsubsection{Effect of Aging Duration}

Aging duration is another important factor influencing the growth of the produced HAP. Samples $3 \mathrm{~d} 50,9 \mathrm{~d} 50,15 \mathrm{~d} 50$, and $21 \mathrm{~d} 50$ were chosen to study

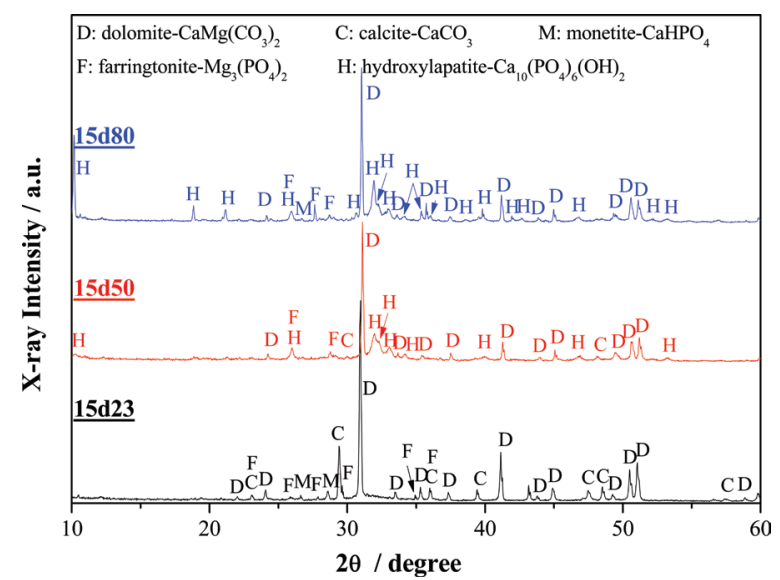

FIGURE 3. XRD patterns of WP-HAP samples aged for $15 \mathrm{~d}$. 
the mineralogical evolution of HAP with aging duration at a fixed aging temperature. The chosen aging temperature was $50^{\circ} \mathrm{C}$, since HAP can be synthesized at this temperature as shown in Figure 2. XRD patterns of these four samples are presented in Figure 4. It can be seen that longer aging duration can lead to a more complete reaction between WP and the DAP solution, as indicated by the change in the major peaks of dolomite at $2 \theta=30^{\circ}$ and calcite at $2 \theta=29^{\circ}$. As shown in Figure 4, these two peaks gradually decrease or completely disappear with the aging duration. Meanwhile, more calcium phosphates are formed, especially HAP. At the aging duration of $3 \mathrm{~d}$, the main peak of HAP at $2 \theta=32^{\circ}$ appears as a hump, indicating low crystallinity of the produced HAP. When the aging duration is $9 \mathrm{~d}$ or longer, peaks of HAP at this position become sharper, implying that the produced HAP has higher crystallinity.

\subsection{Morphological Evolution of the Produced WP-HAP Samples}

Morphology of the WP-HAP samples varied with the aging duration and temperature, as revealed by the SEM images shown in Figure 5. Figures 5(A) and (a) represent the SEM image and a close-up of the untreated WP powder, respectively. It can be seen that the WP particles have an irregular shape, consisting of smaller particles cemented together by the binder (Figure 5a). Figures 5(B) and (b) to (D) and (d) show the morphology change of the WP after reacting with the DAP solution. Figure 5(B) shows the morphology of the $3 \mathrm{~d} 23$ sample. It can be seen that many spherical particles are formed and have aggregated on the unreacted WP particles. The close-up of this figure (Figure $5 \mathrm{~b}$ ) reveals that the surface of the WP-HAP particle is covered by a layer of leaf-like reaction products (mainly calcium or magnesium phosphates such as monetite

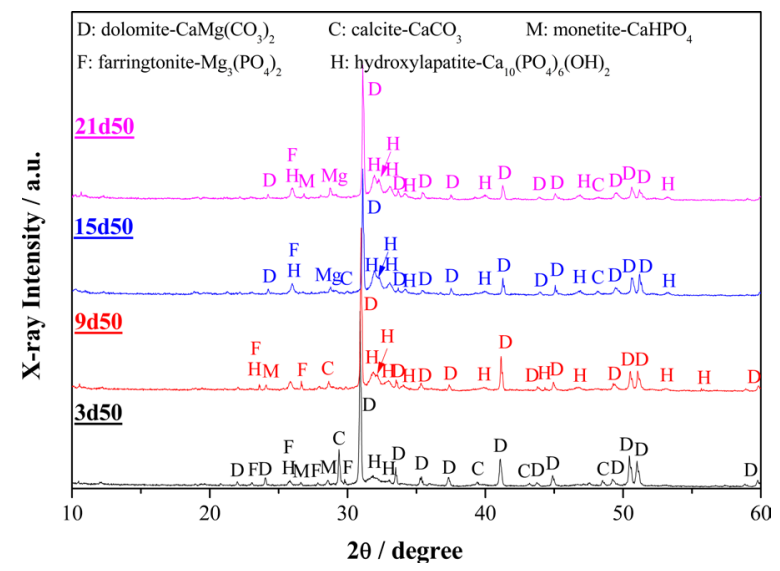

FIGURE 4. XRD patterns of WP-HAP samples aged at $50^{\circ} \mathrm{C}$. and farringtonite), as identified by XRD analysis shown in Figure 2. When the reaction temperature was raised to $50^{\circ} \mathrm{C}$, more hydration products were produced, and most of the WP particle surface was covered by the reaction products. This suggests that the reaction between the WP and DAP is more complete, due to the higher reaction temperature used to produce the $3 \mathrm{~d} 50$ sample. Figure 5(c) shows the morphology of the reaction products of this sample, which is very similar to that of the $3 \mathrm{~d} 23$ sample. At $80^{\circ} \mathrm{C}$, leaf-like reaction products similar to those in $3 \mathrm{~d} 23$ and $3 \mathrm{~d} 50$ samples can be identified, as shown in Figures 5(D) and (d). However, details of the reaction products shown in Figure 5(d) reveals that some reaction products aggregated into larger and denser particles, leading to a smaller surface area. Figures 5(E) and (e) show the effect of a longer aging duration on the morphology of the HAP produced at $23^{\circ} \mathrm{C}$. After aging for $15 \mathrm{~d}$, more products were found produced on the surface of the WP particles than those after aging for $3 \mathrm{~d}$ (Figure 5(b)). When the reaction temperature was increased to $50^{\circ} \mathrm{C}$, much denser rod-like hydration products were formed and were found coated on the particles (17), as shown in Figures $5(\mathrm{~F})$ and $(\mathrm{f})$. The morphology is similar to that of the $3 \mathrm{~d} 80$ WP-HAP sample. Figure $5(\mathrm{G})$ presents the WP-HAP produced after aging for $15 \mathrm{~d}$ at $80^{\circ} \mathrm{C}$, which is similar to the WP-HAP produced after aging for $3 \mathrm{~d}$ at the same temperature (Figure 5(D)). However, the detailed morphology of the reaction products deposited on the surface of the WP powder shown in Figure $5(\mathrm{~g})$ is quite different from the one shown in Figure 5(d). The rod-like products present in Figure 5(d) disappear in Figure $5(\mathrm{~g})$. Clearly, longer aging duration allows the reaction products to fuse and aggregate into denser and larger particles.

The features of the produced WP-HAP samples revealed by SEM imaging can be further confirmed by their BET areas, as shown in Figure 6. The BET area of the untreated WP $(0 \mathrm{~d}$ aging in Figure 6$)$ is $1.855 \mathrm{~m}^{2} / \mathrm{g}$. This surface area was increased to $15.946 \mathrm{~m}^{2} / \mathrm{g}$ after the reaction with DAP and aging for $3 \mathrm{~d}$ at $23^{\circ} \mathrm{C}$. This $768 \%$ increase of the surface area is induced by the leaf-like porous reaction products deposited on the surface of the WP particles, as shown in Figures 5(B) and (b). This surface area can be further improved to 27.986 $\mathrm{m}^{2} / \mathrm{g}$ after aging for $3 \mathrm{~d}$ at $50^{\circ} \mathrm{C}$, which is also in agreement with the SEM image shown in Figures 5(C) and (c). However, when the aging temperature was further increased to $80^{\circ} \mathrm{C}$, the $\mathrm{BET}$ area of the produced WP-HAP sample reduced to $9.154 \mathrm{~m}^{2} / \mathrm{g}$. As shown in Figure 5(d), some smaller particles of the reaction products fused/ aggregated into denser/larger particles at this temperature, leading to a lower surface area. Longer aging duration $(15 \mathrm{~d})$ appears to increase the BET 

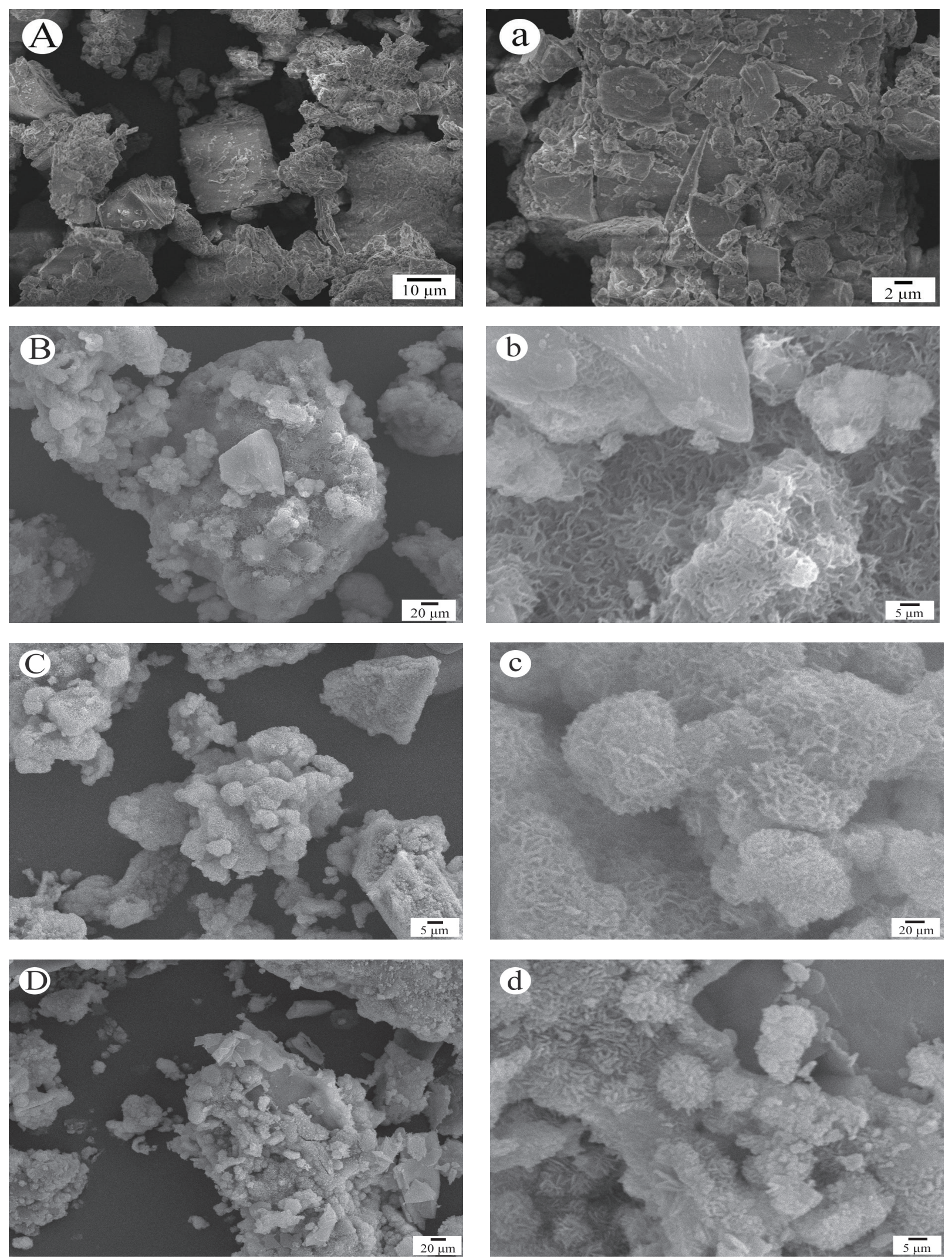

FIGURE 5. Typical SEM images of WP and WP-HAP samples: (A)/(a) WP; (B)/(b) 3d23; (C)/(c) 3d50; (D)/(d) 3d 80; (E)/(e) 15d23; (F)/(f) 15d50; (G)/(g) 15d 80 . 

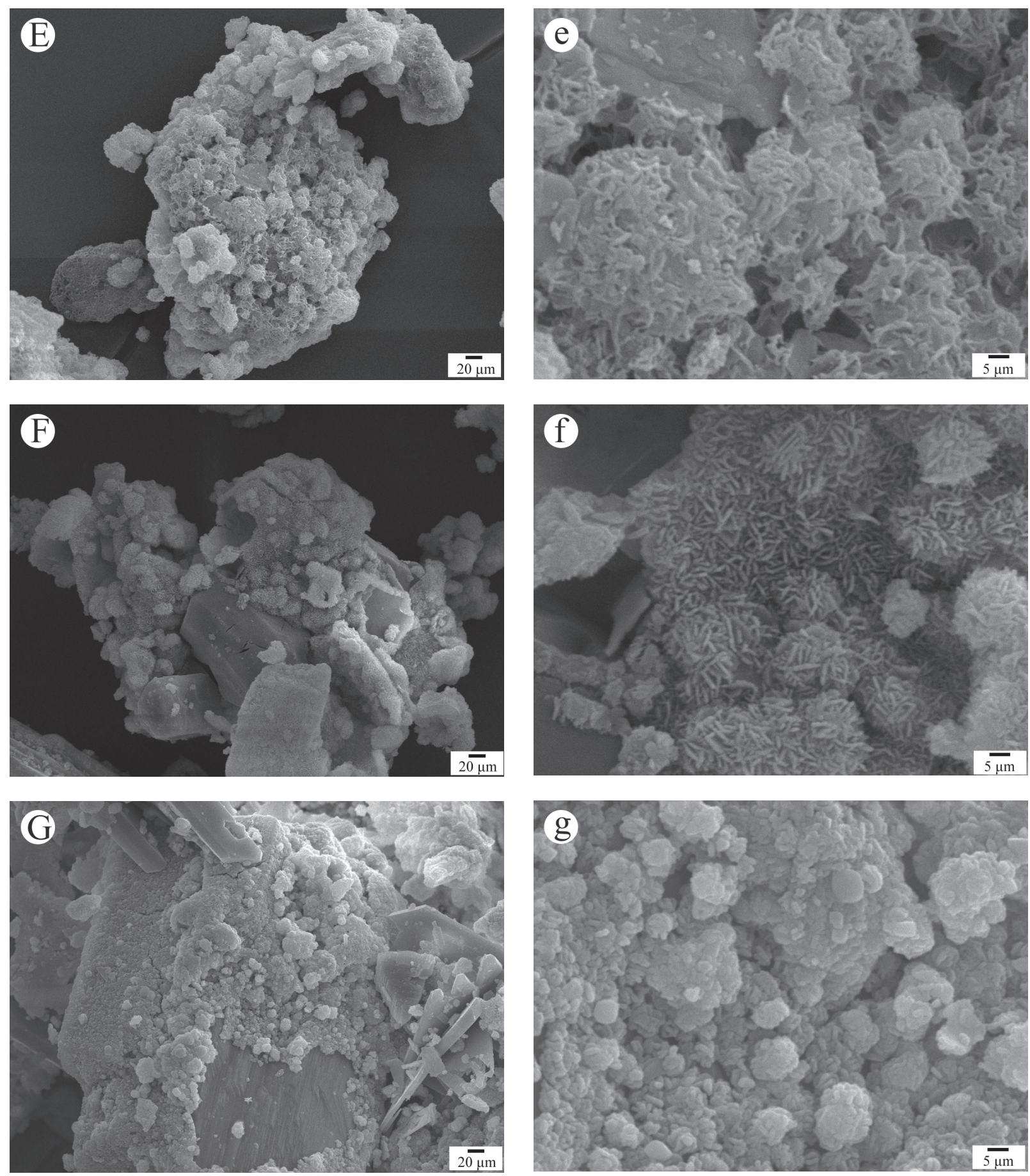

Figure 5. (Continued) Typical SEM images of WP and WP-HAP samples: (A)/(a) WP; (B)/(b) 3d23; (C)/(c) 3d50; (D)/(d) 3d80; (E)/(e) 15d23; (F)/(f) 15d50; (G)/(g) $15 \mathrm{~d} 80$.

area of the WP-HAP produced to $23.305 \mathrm{~m}^{2} / \mathrm{g}$ at an aging temperature of $23^{\circ} \mathrm{C}$. However, at higher aging temperatures (both $50^{\circ} \mathrm{C}$ and $80^{\circ} \mathrm{C}$ ), longer aging duration $(15 \mathrm{~d})$ reduced the BET area of the produced WP-HAP powder. This is because HAP particles grew larger or fused into large particles, as shown in Figure 5.

Larger surface area is desirable for adsorbing heavy metals $(12,29)$. Figure 6 shows that there exist an optimal duration and temperature of aging, 


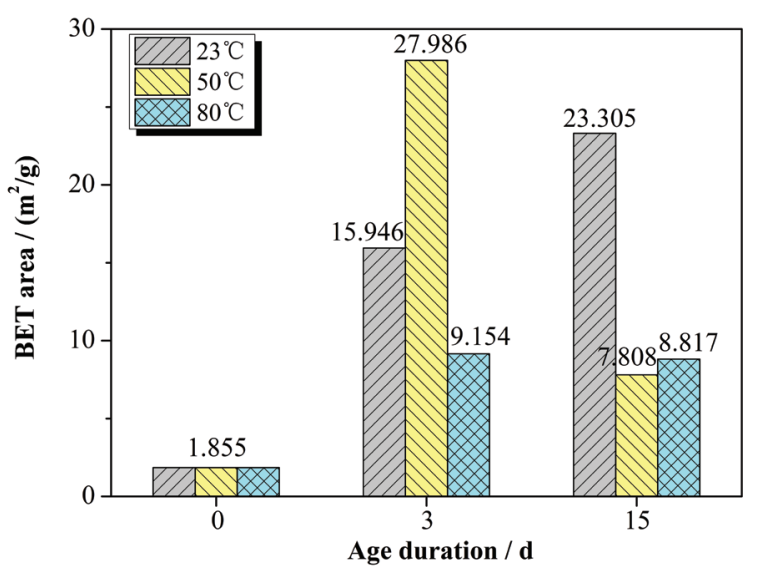

FIGURE 6. BET areas of WP and WP-HAP samples.

at which the BET surface area of the produced WP-HAP reaches the maximum. Under this optimal condition, the proposed method can increase the surface area of the untreated WP powder by at least 15 times, providing more sites for adsorbing the heavy metal ions.

\subsection{Confirmation of Ion-exchange of the Synthesized WP-HAP with $\mathrm{Ni}^{2+}$}

Figure 7 presents the XRD pattern of the produced 15d50 WP-HAP sample after adsorption testing. The most noteworthy difference in this pattern from the one shown in Figure 3 is that a new crystal, arupite $\left(\mathrm{Ni}_{3}\left(\mathrm{PO}_{4}\right)_{2} \cdot 8 \mathrm{H}_{2} \mathrm{O}\right.$, JCPDS, No. 46-1388), appears with the main peak at $2 \theta=13.4^{\circ}$, which is consistent with the findings of De Angelis in their adsorption experiments (15). The production of arupite in this sample clearly confirms the ion-exchange between $\mathrm{Ca}$ and $\mathrm{Ni}$. This is because the ionic radius of $\mathrm{Ni}^{2+}(0.69 \AA)$ is close to that of $\mathrm{Ca}^{2+}(0.99 \AA)$ and that enables $\mathrm{Ni}^{2+}$ to replace $\mathrm{Ca}^{2+}$ in the HAP crystal lattice $(15,16)$.

Ion-exchange with $\mathrm{Ni}^{2+}$ also modified the morphology of the produced WP-HAP sample, as revealed by the SEM images shown in Figure 8. It can be clearly seen that the surface of the sample has been significantly modified by the $\mathrm{Ni}^{2+}$. The rodlike HAP particles on the surface of the WP-HAP sample (Figures 5(F) and (f)) turned into platelets. These platelets can be determined as arupite, according to the XRD result (Figure 7) and EDS shown in Figure $8(\mathrm{c})$. This suggests that $\mathrm{Ni}^{2+}$ can be permanently adsorbed and stabled by the produced WP-HAP (11). Therefore, the waste putty has been successfully upcycled into value added heavy metal adsorbent.

$\mathrm{Ni}$ content in the 15d50 WP-HAP sample after the adsorption test was measured by ICP-OES. The adsorption capacity of this sample for $\mathrm{Ni}^{2+}$ is

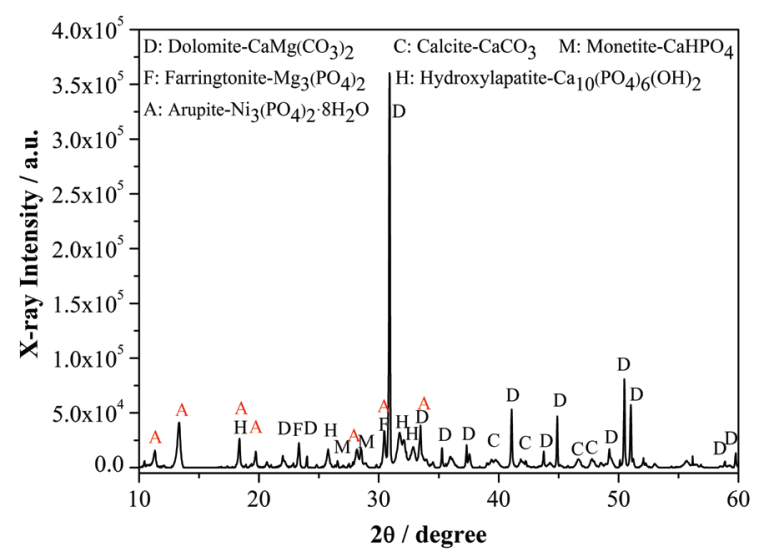

FigURE 7. XRD patterns of WP-HAP samples (15d50) after adsorption of $\mathrm{Ni}^{2+}$. (A: arupite; D: dolomite; C: calcite; $\mathrm{M}$ : monetite; F: farringtonite; H: hydroxylapatite)

$15 \mathrm{mg} / \mathrm{g}$. This adsorption capacity is not high but is still comparable to other reported available adsorbents for $\mathrm{Ni}^{2+}$, i.e., $35.8 \mathrm{mg} / \mathrm{g}$ of barley straw (30), $18.42 \mathrm{mg} / \mathrm{g}$ of tea factory waste (31), $7.63 \mathrm{mg} / \mathrm{g}$ of phosphate rock (32). This is because only the surface of the WP has been converted into HAP by the proposed method. To improve the adsorption capacity of the WP-HAP, one can grind the WP into finer particles. This will increase the surface area of the WP, providing more reaction area between the WP and the DAP. As a result, more HAP can be produced that can greatly increase the adsorption capacity of the produced WP-HAP.

\section{CONCLUSIONS}

A method to upcycle non-structural C\&D wastes as a heavy metal adsorbent is demonstrated in this study. Experimental study confirmed that HAP can be produced on the surface of waste putty particles by soaking the WP particles in a DAP solution at temperatures higher than $23^{\circ} \mathrm{C}$. Higher aging temperature or longer aging duration is beneficial to the yield and crystallinity of the produced HAP crystals. Adsorption testing confirmed that ion-exchange of $\mathrm{Ca}^{2+}$ with $\mathrm{Ni}^{2+}$ in the produced HAP does take place, leading to the formation of arupite. Although a modest adsorption capacity for $\mathrm{Ni}^{2+}(15 \mathrm{mg} / \mathrm{g})$ was achieved by the produced adsorbent due to the relatively large particle size of the WP, much higher adsorption capacity for heavy metal can be achieved by using finer WP powder.

The proposed wet chemical method for WP reuse is simple and cost-effective. More research will be carried out to optimize the manufacturing process and enhance the adsorption capacity of the new waste construction putty-based heavy metal adsorbent. 

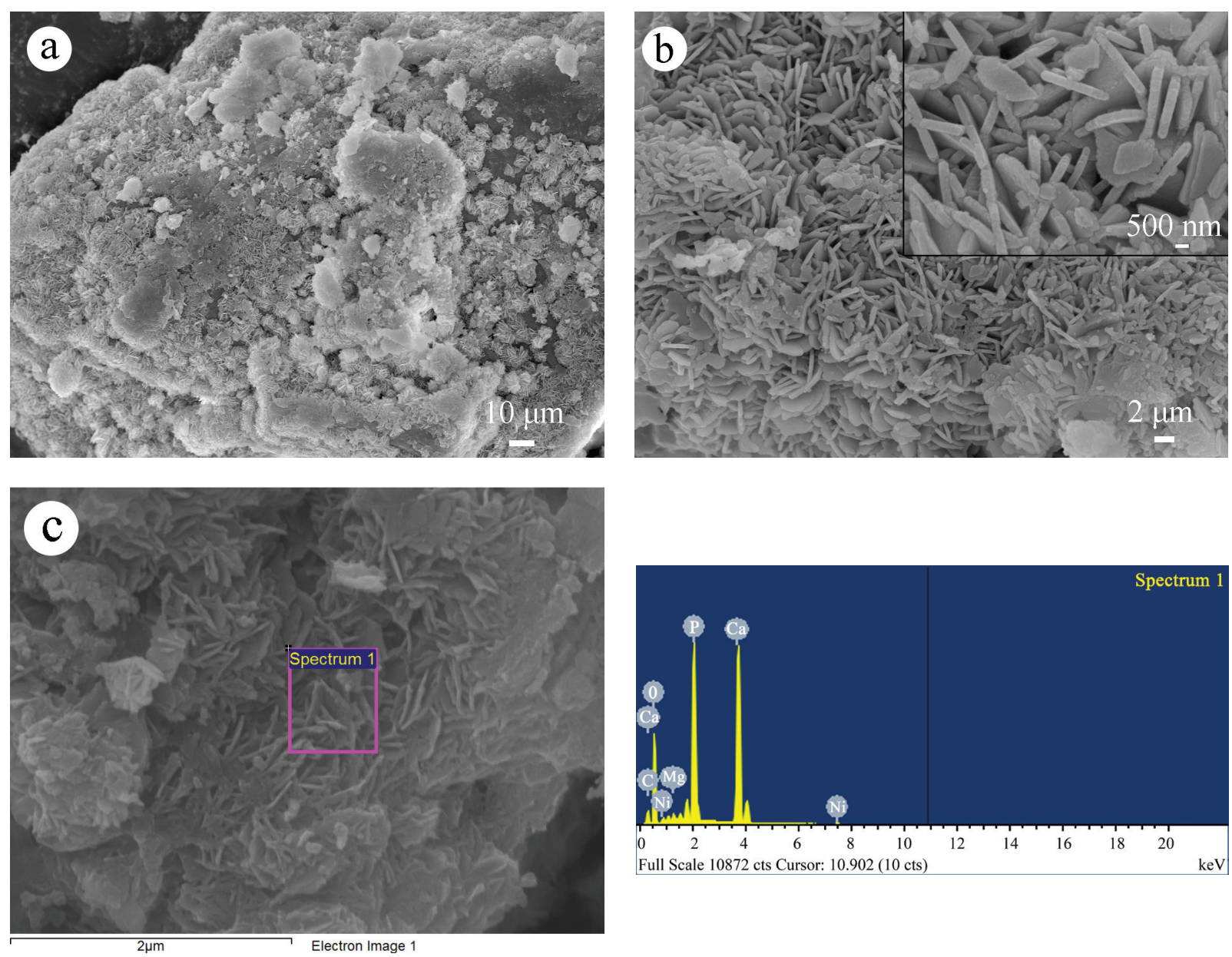

FIGURE 8. SEM images and EDS result of WP-HAP (15d50) samples after adsorption testing: (a) and (b) SEM; (c) EDS result.

\section{ACKNOWLEDGMENTS}

This work was supported by China Postdoctoral Science Foundation(NO. 2018M632518), Anhui Postdoctoral Science Foundation (NO.2017B150 and 2018B248), Natural Science Foundation of Anhui University(KJ2018A0074), Key Research and Development Program Project of Anhui Province (201904a07020081), Nature Science Foundation of Anhui (1908085QE213) and Huainan Science and Technology Planning Project (2018A363).

CONFLICTS OF INTEREST: The authors declare no conflict of interest.

\section{REFERENCES}

1. Behera, M.; Bhattacharyya, S.K.; Minocha, A.K.; Deoliya, R.; Maiti, S. (2014) Recycled aggregate from C\&D waste \& its use in concrete - A breakthrough towards sustainability in construction sector: A review. Constr. Build. Mater. 68, 501-516. https://doi.org/10.1016/j.conbuildmat.2014.07.003.

2. Evangelista, L.; de Brito, J. (2014) Concrete with fine recycled aggregates: a review. Eur. J. Environ. Civ. Eng. 18, 129-172. https://doi.org/10.1080/19648189.2013. 851038.
3. Silva, R.V.; Neves, R.; de Brito, J.; Dhir, R.K. (2015) Carbonation behaviour of recycled aggregate concrete. Cem. Concr. Compos. 62, 22-32. https://doi.org/10.1016/j. cemconcomp.2015.04.017.

4. Zhang, Z.; Zhang, Y.; Yan, C.; Liu, Y. (2017) Influence of crushing index on properties of recycled aggregates pervious concrete. Constr. Build. Mater. 135, 112-118. https:// doi.org/10.1016/j.conbuildmat.2016.12.203

5. Bravo, M.; de Brito, J.; Pontes, J.; Evangelista, L. (2015) Durability performance of concrete with recycled aggregates from construction and demolition waste plants. Constr. Build. Mater. 77, 357-369. https://doi.org/10.1016/j. conbuildmat.2014.12.103.

6. Butler, L.; West, J.S. Tighe, S.L. (2011) The effect of recycled concrete aggregate properties on the bond strength between RCA concrete and steel reinforcement. Cem. Concr. Res. 41 [10], 1037-1049. https://doi.org/10.1016/j. cemconres.2011.06.004

7. Chen, P.; Wang, J.; Wang, L.; Xu, Y.; Qian, X.; Ma, H. (2017) Producing vaterite by $\mathrm{CO}_{2}$ sequestration in the waste solution of chemical treatment of recycled concrete aggregates. J. Clean. Prod. 149, 735-742. https://doi. org/10.1016/j.jclepro.2017.02.148.

8. Lee, N.K.; Abate, S.Y; Kim, H.-K. (2018) Use of recycled aggregates as internal curing agent for alkali-activated slag system. Constr. Build. Mater. 159, 286-296. https://doi. org/10.1016/j.conbuildmat.2017.10.110.

9. Li, W.; Xiao, J.; Sun, Z.; Kawashima, S.; Shah, S.P. (2012) Interfacial transition zones in recycled aggregate concrete with different mixing approaches. 
Constr. Build. Mater. 35, 1045-1055. https://doi.org/ 10.1016/j.conbuildmat.2012.06.022

10. Wang, L.; Wang, J.; Qian, X.; Chen, P.; Xu, Y.; Guo, J. (2017) An environmentally friendly method to improve the quality of recycled concrete aggregates. Constr. Build. Mater. 144, 432-441. https://doi.org/10.1016/j. conbuildmat.2017.03.191

11. Dong, N.T.; Novák, P.; Vejpravova, J.; Hong, N.V.; Lederer, J.; Munshi, T. (2017) Removal of copper and nickel from water using nanocomposite of magnetic hydroxyapatite nanorods. J. Magn. Magn. Mater. 456, 451-460. https:// doi.org/10.1016/j.jmmm.2017.11.064

12. Fihri, A.; Len, C.; Varma, R.S.; Solhy, A. (2017) Hydroxyapatite: A review of syntheses, structure and applications in heterogeneous catalysis. Coord. Chem. Rev. 347, 48-76. https://doi.org/10.1016/j.ccr.2017.06.009.

13. Dick, T.A.; dos Santos, L.A. (2017) In situ synthesis and characterization of hydroxyapatite/natural rubber composites for biomedical applications. Mater. Sci. Eng. C 77, 874-882. https://doi.org/10.1016/j.msec.2017.03.301.

14. Wu, S.-C.; Hsu, H.-C.; Hsu, S.-K.; Tseng, C.-P.; Ho, W.-F. (2017) Preparation and characterization of hydroxyapatite synthesized from oyster shell powders. Adv. Powder Technol. 28 [4], 1154-1158. https://doi.org/10.1016/j.apt. 2017.02.001

15. De Angelis, G.; Medeghini, L.; Conte, A.M.; Mignardi, S. (2017) Recycling of eggshell waste into low-cost adsorbent for Ni removal from wastewater. J. Clean. Prod. 164, 14971506. https://doi.org/10.1016/j.jclepro.2017.07.085.

16. Mobasherpour, I.; Salahi, E.; Pazouki, M. (2012) Comparative of the removal of $\mathrm{Pb}^{2+}, \mathrm{Cd}^{2+}$ and $\mathrm{Ni}^{2+}$ by nano crystallite hydroxyapatite from aqueous solutions: Adsorption isotherm study. Arab. J. Chem. 5 [4], 439-446. https://doi.org/10.1016/j.arabjc.2010.12.022

17. Ramakrishnan, P.; Nagarajan, S.; Thiruvenkatam, V.; Palanisami, T.; Naidu, R.; Mallavarapu, M.; Rajendran, S. (2016) Cation doped hydroxyapatite nanoparticles enhance strontium adsorption from aqueous system: A comparative study with and without calcination. Appl. Clay Sci. 134, 136-144. https://doi.org/10.1016/j.clay.2016.09.022.

18. Xia, W.-Y.; Feng, Y.-S.; Jin, F.; Zhang, L.-M.; Du, Y.-J. (2017) Stabilization and solidification of a heavy metal contaminated site soil using a hydroxyapatite based binder. Constr. Build. Mater. 156, 199-207. https://doi. org/10.1016/j.conbuildmat.2017.08.149.

19. Corami, A.; Mignardi, S.; Ferrini, V. (2008) Cadmium removal from single- and multi-metal $(\mathrm{Cd}+\mathrm{Pb}+\mathrm{Zn}+\mathrm{Cu})$ solutions by sorption on hydroxyapatite. J. Colloid Interface Sci. 317 [2], 402-408. https://doi.org/10.1016/j.jcis.2007.09.075.

20. Guo, J.; Han, Y; Mao, Y; Wickramaratne, M. (2017) Influence of alginate fixation on the adsorption capacity of hydroxyapatite nanocrystals to $\mathrm{Cu}^{2+}$ ions. Colloid Surf. A-Physicochem. Eng. Asp. 529, 801-807. https://doi. org/10.1016/j.colsurfa.2017.06.075.
21. Ning, Y.; Li, J.; Cai, W.; Shao, X. (2012) Simultaneous determination of heavy metal ions in water using near-infrared spectroscopy with preconcentration by nano-hydroxyapatite. Spectroc. Acta Pt. A-Molec. Biomolec. Spectr. 96, 289-294. https://doi.org/10.1016/j.saa.2012.05.034.

22. Guo, Y.J.; Wang, Y.Y.; Chen, T.; Wei, Y.T.; Chu, L.F.; Guo, Y.P. (2013) Hollow carbonated hydroxyapatite microspheres with mesoporous structure: hydrothermal fabrication and drug delivery property. Mater. Sci. Eng., C. 33 [6], 3166-3172. https://doi.org/10.1016/j.msec.2013.03.040.

23. Pramanik, S.; Agarwal, A.K.; Rai, K.N.; Garg, A. (2007) Development of high strength hydroxyapatite by solidstate-sintering process. Ceram. Int. 33 [3], 419-426. https:// doi.org/10.1016/j.ceramint.2005.10.025.

24. Farzadi, A.; Solati-Hashjin, M.; Bakhshi, F.; Aminian, A. (2011) Synthesis and characterization of hydroxyapatite/ $\beta$ tricalcium phosphate nanocomposites using microwave irradiation. Ceram. Int. 37 [1], 65-71. https://doi. org/10.1016/j.ceramint.2010.08.021.

25. Lak, A.; Mazloumi, M.; Mohajerani, M.S.; Zanganeh, S.; Shayegh, M.R.; Kajbafvala, A; Arami, H.; Sadrnezhaad, S.K. (2008) Rapid Formation of Mono-Dispersed Hydroxyapatite Nanorods with Narrow-Size Distribution via Microwave Irradiation. J. Am. Ceram. Soc. 91 [11], 3580 3584. https://doi.org/10.1111/j.1551-2916.2008.02690.x.

26. Liu, Z. (2015) Research on Yunnan phosphorus gypsum building putty powder of interior wall and evaluation of social benefits. Kunming University of Science and Technology,.(in Chinese)

27. Raval, N.P. Shah, PU; Shah, NK (2016) Adsorptive removal of nickel(II) ions from aqueous environment: A review. Environ. Manage. 179, 1-20. https://doi.org/10.1016/j. jenvman.2016.04.045.

28. Mehta, P.; Kaith, B.S. (2018) A Novel approach for the morphology controlled synthesis of rod-shaped nanohydroxyapatite using semi-IPN and IPN as a template. Int. J. Biol. Macromol. 107, 312-321. https://doi.org/10.1016/j. ijbiomac.2017.08.164

29. Sivaperumal, V.R.; Mani, R.; Nachiappan, M.S.; Arumugam, K. (2017) Direct hydrothermal synthesis of hydroxyapatite/ alumina nanocomposite. Mater. Charact. 134, 416-421. https://doi.org/10.1016/j.matchar.2017.11.016.

30. Thevannan, A.; Mungroo, R.; Niu, C.H. (2010) Biosorption of nickel with barley straw. Bioresour. Technol. 101 [6], 1776-1780. https://doi.org/10.1016/j.biortech.2009.10.035

31. Malkoc, E.; Nuhoglu, Y. (2005) Investigations of nickel(II) removal from aqueous solutions using tea factory waste. J. Hazard. Mater. 127 [1-3], 120-128. https://doi.org/10.1016/j.jhazmat.2005.06.030.

32. Elouear, Z.; Amor, R.B.; Bouzid, J.; Boujelben, N. (2009) Use of Phosphate Rock for the Removal of $\mathrm{Ni}^{2+}$ from Aqueous Solutions: Kinetic and Thermodynamics Studies. J. Environ. Eng. 135 [4], 259-265. https://doi.org/10.1061/ (ASCE)0733-9372(2009)135:4(259). 